\title{
Empirics of Solow growth model in Nepali economy
}

\begin{abstract}
Economic growth model developed by R. M. Solow explained the steady-state equilibrium in long run based on neoclassical production function with factor substitutions and diminishing returns in context of developed economy. As the nature of Nepali economy is different than developed economy, this paper aims to analyze economic growth of Nepal in the Solow growth model standard. Specifically, it aims to examine the effect of saving rate, labor growth and human capital on economic growth. On basis of steady-state equilibrium equation developed by Solow, regression equation is developed to find the effect of exogenous variables saving rate and labor growth rate on per capita GDP. Further, the model is extended by adding human capital as regressor. Data of 44 years of Nepali economy are used to analyze the model. Since time series of all the variables are stationary at first difference and they contain same stochastic trend, coefficients are estimated by using ordinary least square method. The analysis shows that the Solow model is applicable to Nepali economy as the predicted coefficients are very close to estimated coefficients. However, the estimated coefficients are very less than the predicted coefficients of the extended model. Furthermore, coefficient of labor growth rate is statistically insignificant in the extended model.
\end{abstract}

Keywords: Solow model; economic growth; physical capita; human capital, Nepal

\section{Introduction}

\section{Background}

Robert M. Solow developed dynamic economic growth theory in 1956 based on the neoclassical production function with factor substitutions and diminishing returns. Before that Harrod (1939) and Domar (1946) attempted to integrate Keynesian analysis with elements of economic growth focusing on role saving and productivity of capital. Solow (1956) argued that slip from knife-edge equilibrium in Harrod and Domar would generate either growing unemployment or prolonged inflation and this situation would happen due to fixed proportions of labor and capital and absence of technological change. However, Solow (1956) admitted that the bulk of his paper was devoted to a model of long-run growth which accepts all the HarrodDomar assumptions except that of fixed proportions of labor and capital. The Solow model analyzed the dynamic changes in the level of output in an economy as a result of changes in the population growth, the capital accumulation, and the technological progress which are

* Lecturer, Shanker Dev Campus Tribhuvan University (ramesh11p.rp@gmail.com) 
assumed to be determined exogenously. Contrary, endogenous growth theory argued that factors such as capital accumulation, human capital, innovation, externality etc., which are endogenous, influence economic growth (Pack, 1994). For developing countries, the debate between exogenous and endogenous models is less relevant because these models mostly concern on the dynamics of motion growth of advanced industrial economy and not about escaping a poverty trap or even initiating a growth boom (Rao \& Cooray, 2009).

One of the strong arguments in growth literature is that the first-generation growth theories as well as existing growth models are not enough to address the needs of developing country. The new growth literatures also are not particularly useful for most developing countries because they focus on the very long run and incentives for expanding the technological frontier (Pritchett, 2006). In view of Hicks (1965) as cited by Pritchett (2006), growth theory (as we shall understand it) has no particular bearing on underdevelopment economics, nor has the underdevelopment interest played any essential part in its development.

Most of empirical researches on growth models are conducted on cross country analysis considering "one size fits all" but they are not appropriate for diverse economic structures and interpreting the coefficients of policy variables as their growth elasticise. So, country specific studies are more appropriate for country specific growth policies. However, the specifications used by many country specific studies are ad hoc and they do not make clear whether their specifications are based on or how they have derived their specifications from the theoretical growth models. In these studies, growth rate is simply regressed on selected determinants of economic growth (Rao \& Cooray, 2009).

\section{Significance of the study}

Solow (1956) argued that higher capital accumulation increases the per capita output but higher population growth lowers income because the available capital must be spread more thinly over the population of workers. The economy reaches to unique steady-state equilibrium where economy stagnates and technological change is essential to attain the new equilibrium with higher level of living standard. In addition, conditional convergence is a major prediction of Solow growth models. The growth of low per capita income country is higher in comparison to high per capita income country (Mankiw, Romer and Weil, 1992).

However the situation of developing countries may be different. Due to lack of sufficient capital, contribution of capital in production process may be less in comparison to contribution of labor. Many developing countries' growth rate is very far from the conditions of a steadystate.

Many socioeconomic factors are responsible for slow economic growth rate of least developed countries like Nepal, among them vicious circle of poverty is one. Saving rate is low due to poverty which makes less investment gives less output in country. Average economic growth rate of Nepal for last 60 years is 3.8 percent while GDP per capita growth rate is 2 percent. When we calculate for last 30 years the economic growth rate is 4.6 percent and GDP per 
capita growth rate is 3 percent. Similarly, gross of saving in Nepal in 1970, 1980s and 1990s decade was only 16 percent in average (World Bank, 2020). In 2000s and 2010s decade, it increased to 30 percent and 44 percent in average. Similarly the population growth rate of Nepal in 1980s, 1990s, 2000s and 2010s decade are 2.62 percent, 2.10 percent, 2.24 percent and 1.35 percent respectively (CBS, 2014).

Endogenous models focus of the on long run growth where the effect of expanding technological frontiers is analyzed. This is not particularly useful for most developing nations, whose primary interest is in restoring short-to medium-term growth and accelerating technological catch-up by adopting already known innovations (Rao \& Cooray, 2009). The Solow model, when extended, is simpler to estimate and simulate to understand the dynamics of growth. Mankiw, Romer and Weil (1992) argued that the Solow model can explain the observed facts better than the endogenous models.

There are different findings regarding the application of the Solow growth model. The basic Solow model explains the positive effect of saving on growth or living standard of people and negative effect of population growth on it. As the model was explained in context of developed economy and assumes, competitive market and constant returns to scale, is it relevant to developing country like Nepal where market imperfection exists highly? Does saving affect living standard of people? How does labor growth rate affect the growth of economy? Can the model be extended by adding human capital? What will be the effect of human capital on economic growth? These are the basic research questions of this study.

\section{Objectives of the study}

The general objective of the study is to analyze economic growth of Nepal in the Solow growth model standard. The specific objectives are:

- To examine the effect of saving rate and labor growth on living standard based on the textbook Solow model.

- To analyze effect of human capital on economic growth by extending the Solow model.

\section{Review of the growth models}

Classical economists, such as F. Quesnay, A. Smith, T.R. Malthus, D. Ricardo and much later, F.P. Ramsey, A.A Young, J.A. Schumpeter and F.A. Knight provided many of the basic ingredients that appear in modern theories of economic growth (Zarra-Nezhad \& Hosainpour, 2011). Harrod (1939) and Domar (1946) contribution to dynamic analysis of growth model is the landmark in development of growth theory. The next and more important contributions to modern growth theory have been the works of Solow (1956) and Swan (1956). Later, endogenous growth theory developed by Romer (1986) and Lucas (1988) led to a welcome resurgence of interest in the determinants of long-term growth (Pack, 1994). 
Solow (1956), in his model, explained that aggregate production function (APF) is determined by technology, capital and labor. Economy reaches to steady state due two situations where capital deepening ceases. First, wage rises as the marginal productivity of worker increases. Second, the marginal product of capital falls due to law of diminishing returns which leads to fall in returns to capital. In the both cases the capital income and wages stagnated if there is absent of technological progress. Technological change shifts the APF upward with new steady state equilibrium. In this situation, stagnation is broken down and both the wage and return to capital rises along with living standard.

Contrary to Solow model based on diminishing returns, Romer (1986) presented a fully specified model of long-run growth with endogenous technological change in which knowledge is an input with increasing marginal productivity. He argued that growth rates can be increasing over time large countries may always grow faster than small countries In contrast to conditional convergence of the Solow model. Lucas (1988) argued that Solow was "attempting to account for the main features of U.S. economic growth, not to provide a theory of economic development" (p.7). He argued that physical capital is accumulated and utilized under the neoclassical technology, and human capital that enhances the productivity or both labor and physical capital.

Chenery et al. (1986) analyzed the sources of growth in different countries on the bases of the growth accounting approach of Solow (1957). After analyzing the period 1960-73, they concluded that the contribution to growth of the unexplained residual was substantial. Mankiw, Romer and Weil (1992) concluded that the Solow model is capable to explain what it intended to explain. If both physical and human capitals are included, it is consistent with the international evidence of economic growth. But if human capital is ignored in the specification of the production function, it causes overestimation of the share of profits which may also overestimate the level of steady state income. Moreover, they argued that countries with similar technologies and rates of accumulation and population growth should converge in income per capita. Radelet et al. (1997) found that East Asian countries grew faster than the rest of the world because these economies promoted exports through a combination of free trade policy, macroeconomic stability and promotion of foreign investment. In a study, Senhadji (2000) showed that the contribution of total production function to growth is generally small in many less developed countries. The findings support for conditional convergence of the augmented Solow model for countries with different economic structures. Moreover, life expectancy, reserves to import ratio and capital account convertibility enhance economic growth while government consumption, real exchange rate, external debt and war casualties have negative influence on growth. Rao and Cooray (2009) found that an extended version of the Solow (1956) model is more compatible with the status of less developed countries. The results showed that the effect of investment during short to medium term growth is higher and persistent than the long run growth. Sergi et al. (2019) analyzed the relationship between entrepreneurship and economic growth in developed and developing countries. In developed countries innovational networks accelerate the rate of economic 
growth but developing countries require further institutionalization of integration processes in entrepreneurship.

\section{The textbook Solow model Household and Production}

Households are assumed to save a constant fraction $s \in(0,1)$ of their disposable income $(Y)$ and that saving $(S)$ is determined exogenously i.e. $S(t)=s Y(t)$. Households consume remaining fraction (1-s) of $Y(t)$ i.e. $C(t)=(1-s) Y(t)$. All firms in economy have same production function and that represent an aggregate production function for unique final good. The aggregate production function is $\mathrm{Y}(\mathrm{t})=\mathrm{F}[\mathrm{K}(\mathrm{t}),(\mathrm{L}(\mathrm{t}) \mathrm{A}(\mathrm{t})]$ where $\mathrm{Y}(\mathrm{t})$ is total amount of final goods, $\mathrm{K}(\mathrm{t})$ is total capital stock, $\mathrm{L}(\mathrm{t})$ is total employment and $\mathrm{A}(\mathrm{t})$ is technology, at time ' $\mathrm{t}$ '. The production function is labor augmented production function and adopts Harrod-neutral technological progress which implies that an increase in technology A ( $t$ ) increases output as if the economy had more labor (Acemoglu, 2009).

The production function satisfies continuity, differentiability, positive and diminishing marginal products of inputs and constant returns to scale. The production function F: $\mathbb{R}_{+}^{3} \rightarrow$ $\mathbb{R}_{+}$is twice differentiable in $\mathrm{K}$ and $\mathrm{L} . \mathrm{Y}, \mathrm{K}, \mathrm{L} \in \mathbb{R}_{+}$and satisfies $\mathrm{F}_{\mathrm{K}}(\mathrm{K}, \mathrm{L}, \mathrm{A}) \equiv \frac{\partial F(K, \mathrm{~L}, \mathrm{~A})}{\partial K}>$ $0, \mathrm{~F}_{\mathrm{L}}(\mathrm{K}, \mathrm{L}, \mathrm{A}) \equiv \frac{\partial \mathrm{F}(\mathrm{K}, \mathrm{L}, \mathrm{A})}{\partial \mathrm{L}}>0, \mathrm{~F}_{\mathrm{KK}}(\mathrm{K}, \mathrm{L}, \mathrm{A}) \equiv \frac{\partial \mathrm{F}(\mathrm{K}, \mathrm{L}, \mathrm{A})}{\partial^{2} \mathrm{~K}}<0$ and $\mathrm{F}_{\mathrm{LL}}(\mathrm{K}, \mathrm{L}, \mathrm{A}) \equiv \frac{\partial^{2} \mathrm{~F}(\mathrm{~K}, \mathrm{~L}, \mathrm{~A})}{\partial^{2} \mathrm{~L}}<0$. The production function exhibits constant returns to scale in $\mathrm{K}$ and $\mathrm{L}$ that implies it is linearly homogeneous i.e. $F(\lambda K, \lambda L)=\lambda F(K, L)(\lambda>0)$. Similarly, the production function satisfies the Inada conditions $\lim _{\mathrm{K} \rightarrow 0} \mathrm{~F}_{\mathrm{K}}(\mathrm{K}, \mathrm{L}, \mathrm{A})=\infty$ and $\lim _{K \rightarrow \infty} F_{K}(K, L, A)=0$ for all $\mathrm{L}>0$ and all $\mathrm{A}$, and $\lim _{L \rightarrow 0} F_{L}(K, L, A)=\infty$ and $\lim _{L \rightarrow \infty} F_{L}(K, L, A)=0$ for all $K>0$ and all $A$. It shows that the first unit of capital and labor are highly productive but when capital and labor are sufficiently abundant, marginal product is close to zero. Moreover, capital is the unavoidable factor i.e. $\mathrm{F}(0, \mathrm{~L}, \mathrm{~A})=$ 0 for all L and A (Acemoglu, 2009).

\section{Market structure and market clearing condition}

Markets, both product and factor, are assumed to be competitive and the labor market clearing condition is: $L(t)=\bar{L}(t)$ where, $\mathrm{L}(\mathrm{t})=$ demand for labor (level of employment) and $\overline{\mathrm{L}}(\mathrm{t})=$ inelastic labor supply. Similarly the capital market clearing condition is $K(t)=\bar{K}(t)$ where K $(\mathrm{t})=$ capital demand by firms and $\overline{\mathrm{K}}(\mathrm{t})$ = supply of capital by households.

Moreover, capital depreciates exponentially at the rate $\delta \in(0,1)$. Out of 1 unit of capital this period, only $1-\delta$ is left for next period. Investment is sum of change in capital and depreciated capital: $\mathrm{I}(\mathrm{t})=\dot{K}(\mathrm{t})+\delta \mathrm{K}(\mathrm{t})$

\section{Firm optimization and equilibrium}

Goal of firms is to maximize profits. Profit maximization situation of firm at time ' $\mathrm{t}$ ' can be expressed as $\max _{K \geq 0, L \geq 0} F(K(t), L(t), A(t))-R(t) K-W(t) L$. The wage rate for labor $(\mathrm{W})$ and rental rate for capital $(\mathrm{R})$ is determined by their marginal productivity. 


\section{Steady-state equilibrium}

Labor force $(\mathrm{L})$ grows exponentially and it is determined exogenously i.e. $\mathrm{L}(\mathrm{t})=\mathrm{L}(0) \mathrm{e}^{\mathrm{nt}}$ Here, labor growth rate is $\frac{\dot{L}(t)}{L(t)}=n$. The technological progress $\mathrm{A}(\mathrm{t})$ grows exponentially at rate $\mathrm{g}>0$ i.e. $\mathrm{A}(\mathrm{t})=\mathrm{A}(0) \mathrm{e}^{\mathrm{gt}}$ and technological progress $\frac{\dot{A}(t)}{A(t)}=g$. The number of effective units of labor, $\mathrm{A}(\mathrm{t})$ $\mathrm{L}(\mathrm{t})$, grows ate rate $\mathrm{n}+\mathrm{g}$. In equilibrium, aggregate investment is equal to savings i.e. $\mathrm{I}(\mathrm{t})=$ $\mathrm{S}(\mathrm{t})$. Effective capital-labor ratio of the economy is defined as $\mathrm{k}(\mathrm{t})=\frac{K(t)}{A(t) L(t)}$ and the steady- state equilibrium situation is $\frac{\dot{k}(t)}{k(t)}=\frac{s f(k(t))}{k(t)}=(n+g+\delta)$.

\section{Research methodology}

The methodology used by Mankiw, Romer and Weil (1992) for cross country growth analysis is adopted in this country specific growth analysis of Nepal.

\section{Model specification}

Cobb-Douglas production function with constant return to scale $\mathrm{Y}(\mathrm{t})=\mathrm{K}(\mathrm{t})^{\alpha}(\mathrm{A}(\mathrm{t}) \mathrm{L}(\mathrm{t}))^{1-\alpha} \quad(0<$ $a<1$ ) is used to analyze the growth of Nepal where $a$ and 1- $a$ are the output elasticities of capital and labor respectively. To analyze the effect of technological change, labor is augmented to technological progress as a result, the 'effective capital per capita' $k(t)=\frac{k(t)}{A(t)(t)}$ and $\mathrm{y}(\mathrm{t})=\frac{Y(t)}{A(t) L(t)}$. The production function in per capita output and capital is expressed as:

$$
y(t)=k(t)^{a}
$$

The steady-state equilibrium path is $\dot{k}(\mathrm{t})=\mathrm{sk}(\mathrm{t})^{\alpha}-(\mathrm{n}+\mathrm{g}+\delta) \mathrm{k}(\mathrm{t})$. This shows that $\mathrm{k}$ converges to a steady state value $\mathrm{k}^{*}$ defined by $\mathrm{sk}^{* a}=(\mathrm{n}+\mathrm{g}+\delta) \mathrm{k}^{*}$ The value of $\mathrm{k}$ at equilibrium is

$$
k^{*}=\left[\frac{s}{n+g+\delta}\right]^{1 /(1-\alpha)}
$$

The model shows that steady state capital labor ratio is positively related to rate of saving and negatively related to population growth rate. To know effect of $\mathrm{s}$ and $\mathrm{n}$ on real income per capita, substituting [2] into production function [1] and taking logs, we get:

$$
\ln \left[\frac{Y(t)}{L(t)}\right]=\ln \mathrm{A}(0)+\mathrm{gt}+\frac{\alpha}{1-\alpha} \ln s-\frac{\alpha}{1-\alpha} \ln (\mathrm{n}+\mathrm{g}+\delta)
$$

This is the regression equations to analyze the effect of saving and population growth to per capita economic growth. Here, A(0) reflects not only technology (advancement in knowledge) but also the resource endowment, climate, institutions, etc. $\ln \mathrm{A}(0)=\mathrm{a}+\varepsilon$, $\mathrm{a}=$ constant and $\varepsilon$ = random shock.

So, the regression equation at given time- time 0 for simplicity- is:

$$
\ln y=a+\frac{\alpha}{1-\alpha} \ln s-\frac{\alpha}{1-\alpha} \ln (n+g+\delta)+\varepsilon
$$


Mankiw, Romer and Weil (1992) assumed that $\mathrm{s}$ and $\mathrm{n}$ are independent of $\varepsilon$ due to three reasons. They argued, firstly, if $\mathrm{s}$ and $\mathrm{n}$ are endogenous and preference are isoelastic, $\mathrm{s}$ and $\mathrm{r}$ are unaffected by $\varepsilon$. Secondly, endogenous growth theory asserted that saving has too large influence on growth and variation in population growth cannot account for any remarkable variation in real income. These theories emphasized the failure of Solow model which can be examined by maintaining the assumptions that $\mathrm{s}$ and $\mathrm{n}$ are independent of $\varepsilon$. Thirdly, if the model is correct, the elasticities of $y$ with respect to $s$ and $(n+g+\delta)$ are approximately 0.5 and -0.5 assuming capital share in income one third in the basic Solow model. If the coefficients from ordinary least square (OLS) estimation are substantially different from these values, the assumptions can be rejected. This assumption implies that the regression equations can be estimated by ordinary least square method.

\section{Extending the Solow Model by Adding Human Capital}

Role of human capital in economic growth is considered very high. Effect of physical capital in growth is found high than the expected value of theoretical model due to absence of human capital in the model. The extended production function after adding human capital is $Y(t)=$ $\mathrm{K}(\mathrm{t})^{\alpha} \mathrm{H}(\mathrm{t})^{\beta}(\mathrm{A}(\mathrm{t}) \mathrm{L}(\mathrm{t}))^{1-\alpha-\beta}(\alpha+\beta<1)$ where $\mathrm{H}$ is stock of human capital, $\beta$ is output elasticity of human capital and other variables are defined as before. Assuming $s_{k}$ and $s_{h}$ be the fraction of income invested in physical capital and human capital respectively and $y=Y / A L, k=K / A L$ and $\mathrm{h}=\mathrm{H} / \mathrm{AL}$ are quantities per effective labor. The growth of both capital are expressed as

$$
\dot{k}(\mathrm{t})=\mathrm{s}_{\mathrm{k}} \mathrm{k}(\mathrm{t})^{\alpha}-(\mathrm{n}+\mathrm{g}+\delta) \mathrm{k}(\mathrm{t}) \text { and } \dot{h}(\mathrm{t})=\mathrm{s}_{\mathrm{h}} \mathrm{k}(\mathrm{t})^{\alpha}-(\mathrm{n}+\mathrm{g}+\delta) \mathrm{k}(\mathrm{t}) .
$$

Equations [5] imply that economy converge the steady state defined by (Mankiw, Romer and Weil (1992) :

$$
k^{*}=\left[\frac{s_{k}^{1-\beta} s_{h}^{\beta}}{n+g+\delta}\right]^{1 /(1-\beta-\alpha)} \text { and } \quad h^{*}=\left[\frac{s_{k}^{\alpha} s_{h}^{1-\alpha}}{n+g+\delta}\right]^{1 /(1-\beta-\alpha)}
$$

To know effect of $\mathrm{s}$ and $\mathrm{n}$ on real income per capita, substituting [6] into production function and taking logs:

$$
\ln \left[\frac{Y(t)}{L(t)}\right]=\ln \mathrm{A}(0)+\mathrm{gt}-\frac{\alpha+\beta}{1-\alpha-\beta} \ln (\mathrm{n}+\mathrm{g}+\delta)+\frac{\alpha}{1-\alpha-\beta} \operatorname{lns}_{\mathrm{k}}+\frac{\beta}{1-\alpha-\beta} \operatorname{lns}_{\mathrm{h}}
$$

This is the equations to analyze the effect of population growth, accumulation of physical capital and human capital on per capita economic growth.

Similar to equation [4] the regression equation at given time- time 0 for simplicity- is:

$$
\ln y=a+\frac{\alpha}{1-\alpha-\beta} \ln s_{k}-\frac{\alpha+\beta}{1-\alpha-\beta} \ln (n+g+\delta)+\frac{\beta}{1-\alpha-\beta} \operatorname{lns}_{h}+\varepsilon
$$




\section{Data and sample}

The data for this research are from Economic Survey (ES) of government of Nepal, World Development Indicators (WDI) and Penn World Table (PWT). The data covers (44 years) from period 1974 to $2017^{* *}$. Real income: Real income is represented by the gross domestic product (GDP) of Nepal in constant price of 2000/01. Saving is measured as share of real investment in real GDP. The nominal investment is deflated by GDP deflator to find the real investment. Both of these data are taken from ES. Labor force growth rate is measured as the growth rate population of 15 to 64 years and the data are taken from WDI. Depreciation is the proportion capital used and its data is taken from PWT. The technological progress $(\mathrm{g})$ is assumed constants and more or less same throughout world, $\mathrm{g}=0.02$ in US economy (Mankiw, Romar \& Weil, 1992). As the value of ' $g$ ' is not available for Nepal, $g=0.02$ is used in this research. Accumulation of human capital is measured by proxy of total number of students in secondary level and higher education. Though this measure is imperfect, it is proportional to of human capital accumulation (Mankiw, Romar \& Weil, 1992). The model is developed in log-linear model and all the data are converted in natural log. The data are analyzed by using EViews (11.0).

\section{Results and Discussion}

\section{ADF unit root test}

To avoid the spurious regression problem, Augmented Dicky-Fuller (ADF) unit root test is applied to check the stationarity of time series by:

$\Delta \mathrm{Y}_{\mathrm{t}}=\beta_{1}+\beta_{2} \mathrm{t}+\delta \mathrm{Y}_{\mathrm{t}-1}+\sum_{\mathrm{i}=1}^{\mathrm{m}} \alpha_{\mathrm{i}} \Delta \mathrm{Y}_{\mathrm{t}-\mathrm{i}}+\varepsilon_{\mathrm{t}}$

Where $\varepsilon_{t}$ is a pure white noise error term and $Y_{t}$ is a random walk with drift around a stochastic trend. Here the null hypothesis is $\mathrm{H}_{0}$ : Variable has unit root $(\delta=0)$ and alternative hypothesis is $\mathrm{H}_{\mathrm{A}}$ : Variable does not have unit root $(\delta<0)$. This hypothesis is tested by using t-statistic and corresponding probability value. All the variables real GDP per capita(y), physical capital accumulation $\left(\mathrm{s}^{\text {or }} \mathrm{s}_{\mathrm{k}}\right)$, population growth rate $(\mathrm{n}+\mathrm{g}+\delta)$ and human capital accumulation $\left(\mathrm{s}_{\mathrm{h}}\right)$ are non-stationary at level form. But all these variables are stationary at first difference at least at 5 percent level of significance.

The regression of a nonstationary time series on another nonstationary time series may produce a spurious regression. However, it is quite possible that the series having the common trend may not have spurious regression (Gugarati, Porter and Gunasekar, 2009). In the model, all the series are I (1), they contain stochastic trend. Hence, estimation of these variables by OLS may not produce spurious regression. So, the equation [4] and [8] are estimated by using OLS.

** In the Economic Survey time series is given as 1975/76 (in combined two years) as Nepali fiscal year starts from mid-July but in other two sources it is given as 1975 (in a single year). To make uniformity time series $1975 / 76$ of the economic survey is treated as 1975. 


\section{Estimation of textbook Solow model}

Estimated of regression equation [4] by using OLS shows that saving rate has positive relation and the population growth has negative relation to per capita real GDP as predicted by the Solow model. The data in the model fulfills the assumptions of OLS except non autocorrelation; hence the estimators are not efficient and corrected by Cochrane-Orcutt procedure. The transformed regression equation with $\hat{\rho}=0.6341$ gives following estimation.

Table 1: Estimation of textbook Solow model

Dependent Variable: log GDP per working age population

Included observations: 43

Variables

Constant

Coefficien

Standard Error

t-Statistic

Probability

$\ln (\mathrm{I} / \mathrm{GDP})$

3.5700

0.1862

19.1781

0.0000

$\ln (\mathrm{n}+\mathrm{g}+\delta)$

0.5303

0.0610

8.6881

0.0000

$-0.4726$

0.2037

$-2.3196$

0.0256

R-squared

0.6539 F-statistic

37.78112

Adjusted R-squared

0.6366 Probability (F-statistic)

0.0000

Durbin-Watson statistics

1.6394

When saving rate increases by one percent, the real GDP per capita increases by 0.5303 percent. Similarly, one percent increases population growth decreases the real GDP per capita by 0.4726 percent. The coefficient of saving is almost 0.5 and coefficient of population growth rate is close to -0.5 . Both the coefficients support the value of output elasticity of capital $a$ equal to one third as used by Mankiw, Romar and Weil (1992). Constant term and saving rate are statistically significant at less than 1 percent level and the population growth combined with depreciation and technological growth is significant less than five percent level. The $\mathrm{F}$ statistics shows that the model is overall significant at less than one percent level. The DW statistics is 1.6394 which is statistically significant at five percent level. Value of adjusted $R^{2}$ shows that about 64 percent of the variations in real GDP are explained by the changes in the saving rates and population growth rates. The model fulfills the all the assumptions of OLS like normal distribution of error terms, homoskedasticity and absence of multicolinearity.

\section{Estimation of extended Solow model}

Regression equation [8] of extended Solow model with human capital is estimated by using OLS. The model shows that physical capital accumulation rate as well as human capital accumulation rate has positive relation to per capita real GDP and the population growth has negative relation to per capita real GDP as predicted by the Solow model. In this model also the estimators fulfill the assumptions of OLS except non autocorrelation; hence the estimators are not efficient and corrected by Cochrane-Orcutt procedure. The transformed regression equation with $\hat{\rho}=0.7931$ gives following estimation. 
Table 2: Estimation of extended Solow model

\begin{tabular}{lrrrr}
\hline $\begin{array}{l}\text { Dependent Variable: log GDP per working age population } \\
\text { Included observations: } 43\end{array}$ & \multicolumn{5}{c}{} & \\
Variables & Coefficient & Standard Error & t-Statistic & Probability \\
Constant & 1.6453 & 0.0965 & 17.0521 & 0.0000 \\
$\ln (\mathrm{I} / \mathrm{GDP})$ & 0.1707 & 0.0486 & 3.5144 & 0.0011 \\
$\ln (\mathrm{n}+\mathrm{g}+\delta)$ & 0.0559 & 0.1374 & 0.4067 & 0.6865 \\
$\ln ($ human capital) & 0.2024 & 0.0302 & 6.7114 & 0.0000 \\
R-squared & 0.7118 & F-statistic & & 32.1075 \\
Adjusted R-squared & 0.6896 & Probability (F-statistic) & \\
Durbin-Watson statistics & 1.7654 & & & 0.0000 \\
\hline
\end{tabular}

After including the human capital in the Solow growth model, the estimated coefficients do not represent the expected value the coefficient of the model. In case of population growth rate, the estimated sign is positive but in model it is expected to be negative and it is statistically insignificant also. However, the F statistics shows that the model is overall significant at less than one percent level. The real GDP per capita increases by 0.1707 percent at one percent increase in physical capital accumulation and it increases by 0.2024 percent at one percent increase in human capital accumulation. The coefficient of physical capital accumulation and human capital accumulation are very far from 1 and does not support the value of output elasticity of physical capital $\alpha$ and human capital $\beta$, both equal to one third as used by Mankiw, Romar and Weil (1992). The DW statistics is 1.7654 which is statistically significant at five percent level. Value of adjusted $R^{2}$ shows that about 69 percent of the variations in real GDP are explained by the changes in the explanatory variables. Like in previous model, the model fulfills the all the assumptions of OLS like normal distribution of error terms, homoskedasticity and absence of multicolinearity.

\section{Conclusions and implications}

The empirical analysis of 44 years data of Nepali economy supports the textbook Solow model. The coefficients of saving and population have the predicted sign and are highly significant. Values of coefficients are also as expected by the model. The data of Nepali economy is supportive to explain the positive effect of saving on growth or living standard of people and negative effect of population growth on it. However, the value of $\alpha$ assumed as one third is for developed economy and in case of developing country it may be less because these countries use labor intensive technology.

According to the model, after extending it by adding the human capital accumulation, effect of physical capital accumulation and population growth rate should increase. But findings of this research show that combined effect of physical capital accumulation and human capital accumulation is less than previous model. Furthermore, the effect of population growth is statistically insignificant and has opposite sign than expected. 
Mankiw, Romar and Weil (1992) justified the extension of model because coefficient of physical capital accumulation was very high then expected coefficient of the model and after extension of the model it came closer to the expected coefficient of the model. But, in findings of this research, the coefficients of the model without including human capital are very closer to expected coefficients of the Solow model and they are far from expected coefficients of extended Solow model. This result may be due to imperfect proxy measurement of human capital accumulation by number of students. This result suggests for accurate measurement of human capital accumulation.

Though the Solow model designed to observe steady state growth in the advanced countries and its use policy needs is controversial for developing countries, country specific analysis of Nepal finds it relevant. The dual economy of Nepal has industrial sector with more capital use and agriculture sector with more labor use. Nepali economy can get benefit from factor substitutability of both sectors. Moreover, per capita capital is low due to low capital formation rate in Nepal. Increase in per capita capital of Nepal helps to achieve the sustained economic growth in long run.

\section{Reference}

Acemoglu, D. (2009). Introduction to modern economic growth. New Jersey: Princeton University Press.

CBS. (2104). Population monograph of Nepal: Volume I (population dynamics). Kathmandu: Central Bureau of Statistics.

Chenery, H. B., Robinson, S., Syrquin, M., \& World Bank. (1986). Industrialization and growth: A comparative study. New York: Published for the World Bank [by] Oxford University Press.

Domar, E.D. (1946). Capital expansion, rate of growth and employment. Econometrica, 14, 137-147.

Harrod, R.F. (1939). An essay in dynamic theory. The Economic Journal, 49 (193), 14-33.

Lucas, R.E. (1988). On the mechanics of economic development. Journal of Monetary Economics, 22, 3-42.

Mankiw, N. G., Romer, D., \& Weil, D. N. (1992). A contribution to the empirics of economic growth. Quarterly Journal of Economics, 2, 407-437.

Pack, H. (1994). Endogenous growth theory: Intellectual appeal and empirical shortcomings. Journal of Economic Perspectives, 8, 55-72.

Pritchett, L. (2006). The quest continues. Finance and Development, 43(1).

Radelet, S. Sachs J., \& Lee J. (1997). Economic growth in Asia. Background Paper for the Asian Development Bank's Emerging Asia Study. HIID Development Discussion Paper No. 609. http://pdf.usaid.gov/pdf_docs/PCAAA746.pdf 
Rao, B. B., \& Cooray, A. (2009). How useful is growth literature for policies in the developing countries? WP 09-09 Department of Economics, University of Wollongong, https://ro.uow. edu.au/commwkpapers/209.

Romer, P.M. (1986).Increasing returns and long-run growth. Journal of Political Economy, 94, 1002-1037.

Sergi B. S., Popkova E. G., Bogoviz A. V., \& Ragulina J. V.(2019).Entrepreneurship and economic growth: The Experience of developed and developing Countries. Entrepreneurship and Development in the 21st Century. Published online: 11 Apr 2019; 3-32. https:/ / doi. org/10.1108/978-1-78973-233-720191002

Senhadji, A. (2000). Sources of economic growth: An extensive growth accounting exercise. IMF Staff Papers 47. http:/ / ssrn.com/abstract=880604

Solow, R. M. (1956). A contribution to the theory of economic growth. The Quarterly Journal of Economics, 70(1), 65-96.

Swan, T. W. (1956). Economic growth and capital accumulation. Economic Record, 32(2), 334361.

World Bank. (2020). World development indicators. The World Bank, https://databank. worldbank.org/source/world-development-indicators .

Yaghmaian, B.(1994). An empirical investigation of exports, development and growth in developing countries: Challenging the neoclassical theory of export led growth. World Development, 22(12), 1977-1995.

Zarra-Nezhad, M., \& Hosainpour, F. (2011). Review of growth models in less developed countries. The International Journal of Applied Economics and Finance, 5, 1-17. 